IJIET, e-ISSN 2548-8430, p-ISSN 2548-8422, Vol. 1, No. 1, January 2017

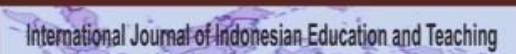

IJIET

International Journal of Indonesian Education and Teaching http://e-journal.usd.ac.id/index.php/IJIET

Sanata Dharma University, Yogyakarta, Indonesia

\title{
A COMPARATIVE STUDY ON DIGITAL-BASED AND NON-DIGITAL- BASED LEARNING MANAGEMENTS IN SANATA DHARMA UNIVERSITY YOGYAKARTA
}

\author{
C. Teguh Dalyono and Y.M.V. Mudayen \\ Sanata Dharma University \\ constteguh@usd.ac.id and mudayen@live.com \\ https://doi.org/10.24071/ijiet.v1i1.331
}

\begin{abstract}
This study aims to: 1) determine whether there is a significant difference in effectiveness of learning management by lecturers of USD who use Digital Learning Resources (SBD) with those who do not use SBD based on the students' perception; 2) determine whether there is a significant difference in the ability of the lecturers who use the SBD and those who do not use SBD in managing the courses according to the students' perception; 3) determine whether there is a significant difference in the ability of the lecturers who use SBD and those who do not use SBD in empowering students according to the students' perception. This study analyzes the effectiveness of learning management among 38 lecturers USD who consisted of 19 lecturers who use SBD and 19 lecturers who do not use SBD. The data analysis uses independent difference sampling t-test technique.The results of the study are as follows: First, there is a significant difference in the effectiveness of the lecturers who use SBD with those who do not use SBD in learning management according to the students' perception with t-value of 2.405 and asymptote significance (2-tailed) of 0.022 smaller than alpha 0.05 . Second, there is a significant difference in the ability of lecturers who use the SBD with those who do not use SBD in managing the course according to the students' perception with t-value of 2.210 and asymptote significance (2-tailed) of 0.041 smaller than alpha 0.05 . Third, there is no significant difference in the ability of lecturers who use SBD with those who do not use SBD in empowering students with t-value of 2.627 and asymptote significance (2-tailed) 0.013 smaller than alpha 0.05 .
\end{abstract}

Keywords: learning management, course management, student empowerment, digital learning resources.

\section{Introduction}

The development of information and communication technology has brought a tremendous change for the advancement of education (Hidayatullah, 2013). Along with these developments, lecture methods also undergo many developments, either in the aspects of the person, the media or the process. The form of information technology development in education is e-learning. E- Learning is an innovation that has contributed greatly to the change of learning activities (P3MP-LPM, 2012). 
IJIET, Vol. 1, No. 1, January 2017

Students no longer only listen to lectures but also 
perform other activities such as observing, simulating, demonstrating and others. The visualization of teaching materials can be in various formats and forms that are more dynamic and interactive so that the learners will be motivated to engage further in the process of the lecture.

Currently, Sanata Dharma University is optimizing information technology infrastructure to support lectures by using Exelsa Moodle (P3MP-LPM, 2012). With Exelsa Moodle, lecturers can interact with students without any need of physical meeting. Exelsa Moodle allows lecturers give out materials, assignments, as well as grade online. This facility also facilitates students to access learning resources online. However, this has not been optimally used by all lecturers and students in their courses.

Learning management can be done using digital learning resources (SBD) by relying on the applications such as hot potatoes and Moodle-based Exelsa. Hot potatoes is a tool to create question bank. It consists of six applications that can be used to create interactive web-based teaching materials. These six applications included in this software are jcloze, jquiz, jcross, jmatch, jmix, and the masher (P3MP-LPM, 2015). Meanwhile, the Moodle-based Exelsa is developed using plug-in activity big blue button that allows the learning activities to be conducted through streaming (P3MP-LPM, 2012).

However, not all lecturers in Sanata Dharma University utilize this facility. Based on the data from the Center for Development and Learning Quality Assurance (P3MP) LPM USD in 2015, only 35 out of 350 lecturers used Exelsa in managing learning, which consisted of 16 lecturers in odd semester of 2015/2016 and 19 lecturers in the even semester of 2015/2016. That means only 10\% of lecturers took advantage of these learning resources. Most lecturers have not utilized this learning management system.

This study compares the learning management conducted by groups of lecturers who used SBD Exelsa and those who did not use it. The lecturers who used this SBD were those who received grants from P3MP LPM USD in odd semester of 2015/2015, as many as 19 lecturers. This study is based on students' perception in 3 aspects: 1) the effectiveness of the lecturers in managing the overall course, 2) the ability of the lecturers in managing subjects and, 3) the ability of the lecturers in empowering students.

This research is expected to provide information on the learning management that takes place among lecturers who utilized SBD because of the grant and those who did not utilize Exelsa. The lecturers in Sanata Dharma University Yogyakarta have to teach, train, and guide students who live in the era of digital technology. The ability of the lecturers to adapt and deliver materials using digital technology is expected by the students. The students are presumed toprefer learning with lecturers who could use digital technology interestingly, creatively, and innovatively rather than those who still use conventional method with lecturing. Furthermore, the use of technology-based media and multimedia allegedly tends to be preferred by students rather than just using white board. Lecturers who use interactive PowerPoint media, internet, digital learning resources, and instructional videos can attract more students to learn rather than those who use only conventional media. Based on the aforementioned 

background, the researchers are interested in doing in-depth study on "A Comparative Study on Learning Management between Lecturers Using and Lecturers Not Using Digital Learning Resources in Sanata Dharma University Yogyakarta".

Based on the aforementioned formulation, the following are the problem formulations: 1) Is there any significant difference in effectiveness of learning management based on the students' perception? 2) Is there any significant difference in the ability of the lecturers who use the SBD and those who do not use SBD in managing the courses according to the students' perception? 3) Is there any significant difference in the ability of the lecturers who use SBD and those who do not use SBD in empowering students according to the students' perception?

There are several definitions of learning management proposed by education experts. Majid (2007: 6) suggested that learning management is a process of organizing the interaction of learners with teachers and learning resources in a learning environment. One of the competencies required from teachers is competence in managing learning that includes: 1) preparation of lesson planning, 2) implementation of teaching and learning interactions, 3) assessment of learners' learning achievements, 4) implementation of the follow- up assessments (Majid, 2007: 111). In learning activities, management of learning is necessary for learning activities to run well as planned. Therefore, teachers should have a good functional command on approaches to teaching systems, procedures, methods, teaching techniques, teaching material structure and utilization of learning facilities.

Similarly, Rohani (2004: 123) proposed that learning management covers all activities which are directly intended to achieve the specific goals of teaching. The activities include: 1) determination of learners' entry behavior, 2) preparation of lesson plans, 3) provision of information, and 4) assessment. Learning management is intimately associated with classroom management. Through good classroom management, teachers can create a classroom atmosphere which is conducive for the learning process to take place smoothly and systematically.

Bced website (1999) defined learning resources as follow:

Learning resources are defined as information, represented and stored in a variety of media and formats, that assists student learning as defined by provincial or local curricula. This includes but is not limited to, printed materials, video, and software formats, as well as combinations of these formats intended for use by teachers and students.

(http://www.bced.gov.bc.ca/irp/appskill/ asleares.htm January 28, 1999).

Learning resource is defined as information presented and stored in a media which could help students. The media is not only limited to a certain form, it could be printed, video, software or even combination of various kinds of form that could be used in learning process. Sadiman, et.al. (2008) defined learning resource as anything that could be used for learning, which can be a person, an object, a message, a material, a technique, or even a background.

Juraman (2014: 12) defined educational information as knowledge and insight that contain many things about education. This educational information 
can be accessed on the internet either through a computer or through a smartphone. Especially for android-based smartphones, it can be used to access educational information because it has supporting applications as follows: 1) wiki encyclopedias, 2) online and offline dictionary, 3) digital library, 4) playstorebook, 5) KBBI android, 6) detik.com, 7) open office, 8) PDF reader, 9) google chrome, 10) Mozilla Firefox, and 12) google translate. Further, Juraman (2014: 12) revealed a number of educational information that can be accessed via android smartphones, namely: 1) academic portal, 2) scientific articles, 3) information on scholarships, 4) wikipedia.org, 5) detik.com, 6) google books, and

7) e-journal. These various types of educational information can be easily accessed by smartphone provided if it is connected to the internet.

\section{Research Method}

This is a comparative study comparing the effectiveness of lecturers' learning management between those who used SBD and those who did not use SBD. The aspects being compared include: 1) overall assessment on learning management effectiveness, 2) lecturers' ability to manage courses, and 3) lecturers' ability to empower students.

The population of this study includes all lecturers, full-time and candidature, in Sanata Dharma University, as many as 350 lecturers. The sample of this research were lecturers who were chosen with specific purpose. Theresearchers employed purposive sampling because they want to examine theeffectiveness of lecturers' learning management among those who used SBD and those who did not use SBD. There were 38 lecturers in this study, 19 of them usedSBD and the rest did not use SBD. The sampling was based on data provided by P3MP LPM USD showing that in the odd semester of 2015/2016, there were 19 lecturers who used SBD; therefore, for comparison, the researchers selected 19 others who did not use SBD. The lecturers who used SBD were those who wonthe grant provided by P3MP LPM USD. The selection of the other group of lecturers was based on the home base of the lecturer who used SBD. Further, the researchers also considered similarity of courses and relative age of both groups. Therefore, both groups of lecturers have relatively the same characteristics.

The study was conducted at Sanata Dharma University which included five campuses: Mrican 1 and 2, Paingan, and Kota Baru. The study was conducted from April 2015 until February 2016. The data collected in this research used the data evaluation filled out online by the students based on a structured and closed questionnaire managed by LPM P3MP USD. The data used was the learning evaluation data in the odd semester of the academic year 2015/2016. In addition to the data from the closed questionnaire, the researchers also used the data in the comments, criticisms, and suggestions of students for each lecturer in which subjects they participated.

The variables and operational definitions in this study were as follows: 1) The effectiveness of learning management is the lecturer's ability to manage learning activities in accordance with the learning objectives that have been delivered at the beginning of the semester. The indicators: the clarity of description of course content and the clarity of description of the overall learning 
activity; 2) The ability to manage the course, namely the expertise of lecturers in managing the dynamics of class for one semester. The indicators: a clear learning objective, depth of knowledge, clarity of concept taught, clarity of content and the sequences; 3) The ability to empower students was lecturers' expertise to design and implement learning scenarios with a focus on involving and enabling all students to participate in class. Indicators: develop critical thinking/creativity, conceptual understanding, and relevance between topics/themes.

The data analysis employed descriptive analysis technique and different independent sample t-test. The descriptive analysis technique was employed to describe the lecturers' ability to manage learning based on the students' perception. It was done using percentage analysis. The lecturers' ability in managing learning was divided into five categories (Arikunto, 2003: 264), i.e.: Very High with score of 6.30-7.0; High with score of 5.60-6.29; Moderate with score 4.55-5.59; Low with score of 3.85-4.54; and Very Low with score of <3.85. The descriptive analysis was used to analyze the first problem of this study.

The different independent sample t-test was used to compare thedifferences of learning management between groups of lecturers who used SBD and those who did not use SBD. The formula of the test is:

$$
t=\frac{X 1-X 2}{S_{X}-x}
$$

Legend:

$\mathrm{t}=\mathrm{t}$ value

$\mathrm{X} 1=$ average of group 1

$\mathrm{X} 2=$ average of group 2

$\mathrm{S}$ X-X $\quad=$ standard error of both groups

This test was employed to analyze the problems number two to five in this study. The criteria: if $t$ value is bigger than $t$ table, so there is a significant difference in the effectiveness of learning management between groups of lecturers who used SBD and those who did not use SBD.

\section{Findings and Discussion}

\section{Characteristics of the Research Subjects}

This study involved 38 USD lecturers as subjects, consisting of 19 lecturers who utilized SBD and 19 others who did not use SBD. The second group was taken from the same study program and those who have more or less the same characteristics in terms of courses and work period. The characteristics of the subject based on their study program is shown in the following table. 
IJIET, Vol. 1, No. 1, January 2017

Table 1. Characteristics of the Research Subject Based on Their Home Base

\begin{tabular}{|c|l|c|c|}
\hline No & Study Program & Frequency & Percentage (\%) \\
\hline 1 & Mathematics Education & 6 & 15.8 \\
\hline 2 & Biology Education & 6 & 15.8 \\
\hline 3 & English Language Education & 6 & 15.8 \\
\hline 4 & Catholic Religion Education & 2 & 5.3 \\
\hline 5 & Elementary School Education & 6 & 15.8 \\
\hline 6 & Economic Education & 4 & 10.5 \\
\hline 7 & Accounting & 2 & 5.3 \\
\hline 8 & Management & 2 & 5.3 \\
\hline 9 & Psychology & 4 & 10.5 \\
\hline & & $\mathbf{3 8}$ & $\mathbf{1 0 0}$ \\
\hline & Source: primary data of P3MP LPM USD, processed in 2016 \\
\hline
\end{tabular}

From the table above, it can be seen that the subjects were taken from nine study programs in Sanata Dharma University. The subjects were mostly from four study programs, i.e. 1) Mathematics Education, 2) Biology Education, 3) English Language Education, and 4) Elementary School Education. In each study program, there were three lecturers who utilized SBD and when being combined with the lecturers who did not use SBD, it became six in each study program. There were three study programs in which two lectures were chosen, i.e. 1) Catholic Religion Education, 2) Accounting, and 3) Management. In these study programs, there were only one lecturer who used SBD and when being combined with that who did not use SBD, it became two in each study program.

The small number of subjects in this study showed that there was small number of lecturers who used SBD. Further, it also showed that there is a small number of study program that utilized SBD. Even overall in USD, there was a large number of lecturers from 20 other study programs who did not use SBD. This implied that most lecturers did not utilize Exelsa, the web-based SBD.

\section{Data Analysis}

\section{Comparative Analysis of Learning Management Effectiveness}

The mean, deviation standard, and test result of differences on lecturers' ability in managing learning according to students' perception could be seen below: 
Table 2. Mean and Deviation Standard of Overall Assessment

\begin{tabular}{|c|l|c|c|c|c|}
\hline \multicolumn{2}{|c|}{ Group Statistics } & & \multicolumn{1}{c|}{\begin{tabular}{c} 
Std. \\
Dtd. \\
\cline { 2 - 6 }
\end{tabular}} & $\begin{array}{c}\text { Error } \\
\text { Meviation }\end{array}$ & Mean \\
\hline Overall Assessment & $\begin{array}{l}\text { Using Digital Learning } \\
\text { Resources }\end{array}$ & 19 & 6.0368 & .45730 & .10491 \\
\cline { 2 - 6 } & $\begin{array}{l}\text { Not Using Digital } \\
\text { Learning Resources }\end{array}$ & 19 & 5.7211 & .34412 & .07895 \\
\hline
\end{tabular}

Source: primary data of P3MP LPM USD, processed in 2016

According to the table above, it can be seen that the overall assessment of the ability of lecturers who used SBD has a mean value of 6.0368 and the standard deviation of 0.45730. Meanwhile, lecturers who did not use SDB has a mean value of 5.7211. The benchmark using Reference Manual Type I showed that both groups of lecturers who used SBD and those who did not use SBD were high. However, to determine whether there is a significant difference in the ability of lecturers to manage the overall learning, difference test was conducted.

Table 3. Difference Test of Lecturers' Ability in Managing Learning

\begin{tabular}{|c|c|c|c|c|c|c|c|c|c|c|}
\hline \multicolumn{11}{|c|}{ Independent Samples Test } \\
\hline & & \multicolumn{2}{|c|}{\begin{tabular}{|c|} 
Levene's Test \\
for Equality of \\
Variances \\
\end{tabular}} & \multicolumn{7}{|c|}{ t-test for Equality of Means } \\
\hline & & \multirow[b]{2}{*}{$\mathrm{F}$} & \multirow[b]{2}{*}{ Sig. } & \multirow[b]{2}{*}{$\mathrm{T}$} & \multirow[b]{2}{*}{ Df } & \multirow{2}{*}{$\begin{array}{l}\text { Sig. } \\
(2- \\
\text { tailed })\end{array}$} & \multirow{2}{*}{$\begin{array}{c}\text { Mean } \\
\text { Difference }\end{array}$} & \multirow{2}{*}{$\begin{array}{l}\text { Std. Error } \\
\text { Difference }\end{array}$} & \multicolumn{2}{|c|}{$\begin{array}{c}95 \% \\
\text { Confidence } \\
\text { Interval of the } \\
\text { Difference }\end{array}$} \\
\hline & & & & & & & & & Lower & Upper \\
\hline \multirow[t]{2}{*}{$\begin{array}{l}\text { Overall } \\
\text { Assessment }\end{array}$} & $\begin{array}{l}\text { Equal } \\
\text { variances } \\
\text { assumed }\end{array}$ & 3.135 & .085 & 2.405 & 36 & .021 & .31579 & .13130 & .04950 & .58207 \\
\hline & $\begin{array}{l}\text { Equal } \\
\text { variances } \\
\text { not } \\
\text { assumed }\end{array}$ & & & 2.405 & 33.436 & .022 & .31579 & .13130 & .04879 & .58278 \\
\hline
\end{tabular}

Source: primary data of P3MP LPM USD, processed in 2016

Based on the difference on the test table above, it can be seen that on the column of equal variance not assumed, the $t$ value was 2.405 and asymptote significance (2-tailed) of 0.022 . Because the value of asymptote significance (2tailed) is smaller than the alpha of 0.05 , it can be concluded that there was a significant difference between the learning management abilities of lecturers who used SBD with those who did not use SBD according to students' perception. The mean value of learning management by lecturers who used SBD was higher than those who did not use SBD. In other words, the overall learning management undertaken by lecturers who used SBD was rated better by the students rather 
than those who did not use SBD.

\section{Comparative Analysis of Lecturers'Ability in Managing Courses}

The comparison of course management ability of lecturers who used SBD and those who did not use SBD could be observed from the mean and deviation standards in the following table:

Table 4. Mean and Deviation Standard of Lecturers' ability in Managing Course

\begin{tabular}{|l|l|c|c|c|c|}
\hline \multicolumn{7}{|c|}{ Group Statistics } \\
\hline & Group Category & $\mathrm{N}$ & Mean & $\begin{array}{c}\text { Std. } \\
\text { Deviation }\end{array}$ & $\begin{array}{c}\text { Std. Error } \\
\text { Mean }\end{array}$ \\
\hline $\begin{array}{l}\text { Ability in } \\
\text { Managing Course }\end{array}$ & $\begin{array}{l}\text { Using Digital Learning } \\
\text { Resources }\end{array}$ & 19 & 5.7158 & .51883 & .11903 \\
\cline { 2 - 6 } & $\begin{array}{l}\text { Not Using Digital } \\
\text { Learning Resources }\end{array}$ & 19 & 5.3895 & .42543 & .09760 \\
\hline
\end{tabular}

Source: primary data of P3MP LPM USD, processed in 2016

Based on the table above, it can be seen that the ability of lecturers who used SBD in managing course had a mean value of 5.7158 and deviation standard of 0.51883. Meanwhile, for lecturers who did not use SBD, the mean was 5.3895 and deviation standard of 0.42543 . From the mean value, it was seen that the ability of lecturers who used SBD is higher than those who did not use SBD. Referring to PAP type I, the mean of lecturers who used SBD was categorized as high and that of lecturers who did not use SBD was moderate.

To identify whether there is a significant difference between lecturers who used SBD and those who did not use SBD in managing courses, difference test was conducted and could be seen below:

Table 5. Difference Test of Lecturers' Ability in Managing Course

\begin{tabular}{|c|c|c|c|c|c|c|c|c|c|c|}
\hline \multicolumn{11}{|c|}{ Independent Samples Test } \\
\hline & & \multicolumn{2}{|c|}{$\begin{array}{c}\text { Levene's Test } \\
\text { for Equality } \\
\text { of Variances }\end{array}$} & \multicolumn{7}{|c|}{ t-test for Equality of Means } \\
\hline & & \multirow[b]{2}{*}{$\mathrm{F}$} & \multirow[b]{2}{*}{ Sig. } & \multirow[b]{2}{*}{$\mathrm{t}$} & \multirow[b]{2}{*}{ df } & \multirow{2}{*}{$\begin{array}{c}\text { Sig. } \\
(2- \\
\text { tailed })\end{array}$} & \multirow{2}{*}{$\begin{array}{c}\text { Mean } \\
\text { Difference }\end{array}$} & \multirow{2}{*}{$\begin{array}{l}\text { Std. Error } \\
\text { Difference }\end{array}$} & \multicolumn{2}{|c|}{$\begin{array}{c}95 \% \\
\text { Confidence } \\
\text { Interval of the } \\
\text { Difference }\end{array}$} \\
\hline & & & & & & & & & Lower & Upper \\
\hline $\begin{array}{l}\text { Ability in } \\
\text { Managing } \\
\text { Course }\end{array}$ & \begin{tabular}{|l} 
Equal \\
variances \\
assumed
\end{tabular} & 1.012 & .321 & 2.120 & 36 & .041 & .32632 & .15393 & .01414 & .63849 \\
\hline
\end{tabular}




\begin{tabular}{|c|c|c|c|c|c|c|c|c|c|c|}
\hline \multicolumn{11}{|c|}{ Independent Samples Test } \\
\hline & & \multicolumn{2}{|c|}{$\begin{array}{l}\text { Levene's Test } \\
\text { for Equality } \\
\text { of Variances }\end{array}$} & \multicolumn{7}{|c|}{ t-test for Equality of Means } \\
\hline & & \multirow[b]{2}{*}{$\mathrm{F}$} & \multirow[b]{2}{*}{ Sig. } & \multirow[b]{2}{*}{$\mathrm{t}$} & \multirow[b]{2}{*}{ df } & \multirow{2}{*}{$\begin{array}{l}\text { Sig. } \\
(2- \\
\text { tailed })\end{array}$} & \multirow{2}{*}{$\begin{array}{c}\text { Mean } \\
\text { Difference } \\
\end{array}$} & \multirow{2}{*}{$\begin{array}{l}\text { Std. Error } \\
\text { Difference } \\
\end{array}$} & \multicolumn{2}{|c|}{$\begin{array}{c}95 \% \\
\text { Confidence } \\
\text { Interval of the } \\
\text { Difference }\end{array}$} \\
\hline & & & & & & & & & Lower & Upper \\
\hline \multirow[t]{2}{*}{$\begin{array}{l}\text { Ability in } \\
\text { Managing } \\
\text { Course }\end{array}$} & \begin{tabular}{|l} 
Equal \\
variances \\
assumed
\end{tabular} & 1.012 & .321 & 2.120 & 36 & .041 & .32632 & .15393 & .01414 & .63849 \\
\hline & \begin{tabular}{|l} 
Equal \\
variances \\
not \\
assumed
\end{tabular} & & & 2.120 & 34.670 & .041 & .32632 & .15393 & .01372 & .63891 \\
\hline
\end{tabular}

Source: primary data of P3MP LPM USD, processed in 2016

From the table above, it is known that in the column of equal variances not assumed, t value was 2.210 and asymptote significance (2-tailed) of 0.041 . Because asymptote significance is smaller than alpha 0.05 , it can be concluded that there was significant difference in the ability of lecturers who used SBD with those who did not use SBD in managing the course according to students' perception. In the previous table, it was understood that the mean of lecturers' ability who used SBD in managing the course was higher than those who did not use SBD. In other words, the lecturers who utilized SBD were considered more competent to manage the course rather than those who did not use SBD.

\section{Comparative Analysis of Lecturers' Ability in Empowering Student}

The following section shows the comparative analysis of the ability of lecturers who used SBD and those who did not use SBD in empowering students during class activities. The comparison could be seen from the mean value and deviation standard in the following table.

Table 6. Mean and Deviation Standard Lecturers' Ability in Empowering Students

\begin{tabular}{|l|l|r|c|r|c|}
\hline \multicolumn{7}{|c|}{ Group Statistics } \\
\hline & Group Category & \multicolumn{1}{c|}{$\mathrm{N}$} & \multicolumn{1}{c|}{ Mean } & \multicolumn{1}{c|}{$\begin{array}{c}\text { Std. } \\
\text { Deviation }\end{array}$} & $\begin{array}{c}\text { Std. Error } \\
\text { Mean }\end{array}$ \\
\hline $\begin{array}{l}\text { Ability in } \\
\text { Empowering } \\
\text { Students }\end{array}$ & $\begin{array}{l}\text { Using Digital Learning } \\
\text { Resources }\end{array}$ & 19 & 5.8474 & .44268 & .10156 \\
\cline { 2 - 6 } & $\begin{array}{l}\text { Not Using Digital } \\
\text { Learning Resources }\end{array}$ & 19 & 5.5211 & .31195 & .07157 \\
\hline
\end{tabular}

Source: primary data of P3MP LPM USD, processed in 2016

From the table above, it can be seen that the mean value for lecturers who 
used SBD in empowering students was 5.8474 with deviation standard of 0.44268 . Meanwhile, the mean value of those who did not use SBD in empowering students was 5.5211. From the mean values, it could be seen that lecturers who used SBD had higher value than those who did not use SBD. Referring to PAP type I, the score for lecturers who used SBD in empowering students belonged to high category; meanwhile, for those who did not use SBD belonged to moderate category. To find out whether there is significant difference of the lecturers' ability in empowering students according to students' perception, difference test should be conducted.

Table 7. Difference Test of Lecturers' Ability in Empowering Students

\begin{tabular}{|c|c|c|c|c|c|c|c|c|c|c|}
\hline \multicolumn{11}{|c|}{ Independent Samples Test } \\
\hline & & \multicolumn{2}{|c|}{$\begin{array}{l}\text { Levene's Test } \\
\text { for Equality } \\
\text { of Variances }\end{array}$} & \multicolumn{7}{|c|}{ t-test for Equality of Means } \\
\hline & & \multirow[b]{2}{*}{$\mathrm{F}$} & \multirow[b]{2}{*}{ Sig. } & \multirow[b]{2}{*}{$\mathrm{t}$} & \multirow[b]{2}{*}{ Df } & \multirow{2}{*}{$\begin{array}{l}\text { Sig. } \\
(2- \\
\text { tailed })\end{array}$} & \multirow{2}{*}{$\begin{array}{c}\text { Mean } \\
\text { Difference }\end{array}$} & \multirow{2}{*}{$\begin{array}{c}\text { Std. Error } \\
\text { Difference }\end{array}$} & \multicolumn{2}{|c|}{$\begin{array}{c}95 \% \\
\text { Confidence } \\
\text { Interval of the } \\
\text { Difference }\end{array}$} \\
\hline & & & & & & & & & Lower & Upper \\
\hline \multirow[t]{2}{*}{$\begin{array}{l}\text { Ability in } \\
\text { Empowering } \\
\text { Students }\end{array}$} & $\mid \begin{array}{l}\text { Equal } \\
\text { variances } \\
\text { assumed }\end{array}$ & 2.797 & .103 & 2.627 & 36 & 013 & .32632 & .12424 & .07435 & .57829 \\
\hline & $\begin{array}{l}\text { Equal } \\
\text { variances } \\
\text { not } \\
\text { assumed }\end{array}$ & & & 2.627 & 32.340 & .013 & .32632 & .12424 & .07335 & .57928 \\
\hline
\end{tabular}

Source: primary data of P3MP LPM USD, processed in 2016

From the table above, it can be seen that in the column of equal variances not assumed, the $\mathrm{t}$ value was 2.627 and asymptote significance (2-tailed) was 0.013 smaller than alpha 0.05 . Therefore, it can be concluded that there was a significant difference on the ability to empower students between lecturers who used SBD and those who did not use SBD. The mean value of those who used SBD is higher than those who did not use SBD. Therefore, it can be concluded that lecturers who used SBD had better ability in empowering students than those who did not use SBD.

\section{Discussion}

\section{Comparison on the Effectiveness of Learning Management}

From the data analysis, it is known that there was a significant difference between the effectiveness of learning management between lecturers who used SBD with those who did not use SBD. Learning management effectiveness of lecturers who used SBD was perceived higher than those who did not use SBD by students participating in the course. The lecturers who used SBD is generally perceived by the students as more qualified to manage learning in comparison to 
those who did not use SBD.

The aspects perceived by students as part of management of this course covered two things: 1) clarity of course content description and; 2) clarity of description of the overall learning activity. A positive perception of the students related to the ability of lecturers who used SBD in managing the course was apparent from criticism, suggestions and comments on the online learning evaluation organized by P3MP LPM USD. Here are some examples of comments from the students on the effectiveness of the learning management by lecturers who used SBD: "For me, this learning management is perfect, although thecontent material is not easy but the lecturer's approach and how to deliver the material has made all the students interested and can understand very well". Another example of the comments: "The learning process went well. I thought I will sleep in this class, but I got carried away so I was not sleepy at all. The lecturer understands how to attract the attention of students". The learning management by lecturers who used SBD was perceived more clearly and systematically because the students have been given the overall picture of the learning activities to be undertaken during the semester. Learning management bylecturers who used SDB was perceived more effective due to the design of the learning activities that were arranged systematically and tailored for the competencies to be achieved.

For the lecturers who did not use digital learning resources in managing learning, there were some criticisms and suggestions, for example: "The flow was less coherent, and during the learning process students did not get basic knowledge or concepts in planning for learning". Another example of the criticism and advice was: "I am disappointed because what we did was not really given reinforcement by the lecturer. I do not fully know the difference of SBC or K13".

However, there are also some positive comments on the management of learning by lecturers who did not use SBD, for example: "This course has helped me in the future to be a creative educator, because here we are taught to create and innovate". Other example of positive comments: "I appreciated very much the ways of learning in the classroom during this time, because the lecturer was always firm and did not allow students to relax".

\section{Analysis on Lecturers' Ability in Managing Course}

From the data analysis, it is known that there was significant difference in the ability of lecturers who used SBD with those who did not use SBD in managing the course according to students' perception. The ability of lecturers who used SBD in managing the course was perceived higher than those who did not use SBD by students participating in the course. The lecturers using SBD was generally perceived by the students better in managing the course compared to those who did not use SBD.

The aspects perceived by students in the management of the course cover five things: 1) ability of the lecturer in explaining the objective of learning; 2) the breadth and depth of knowledge of the lecturer on the course; 3) the clarity of concept taught by the lecturer; 4) the clarity of the material being taught by the 
lecturer; 5) the clarity of sequences in learning. A positive perception of the students related to the ability of lecturers who used SBD in managing the course was apparent from the criticism, suggestions and comments on the online learning evaluation organized by P3MP LPM USD.

In general, the students participating in the course with the lecturers who used SBD feel that the management of the course organized by the lecturers had clear objective, material taught and sequences. Here are some examples of comments from students who attended a course by a lecturer who used SBD: "The flow of material is very neat, so the students are at ease in understanding and following the lesson". Other comment was "Please keep the online tasks". Another example was "The social activity to Panti Cacat Ganda or SLB further enhances the knowledge and understanding of the genetic material. In addition, mutual caring and respect for others with special needs are also fostered through this social activity". There were still many other positive comments about lecturers who used SBD. However, there were also some negative comments for the lecturers who used SBD, for example: "Please don't make the online assignments weekly because there are still many assignments from other courses".

For the group of lecturers who did not use SBD, there were some criticisms and suggestions, for example: "How to teach needs to be clarified. Make it more relaxed and not tense". Other suggestion was as follows: "The learning sequence was less coherent, and during the learning process the students did not get the basic knowledge or concepts in planning learning". Another example was: "The way of teaching is good enough although I have trouble understanding the material, it may be too fast".

However, there were also some positive comments on the lecturers who did not use SBD: "During the lecture, the lecturer always explained very well. I felt very comfortable as a student here. The lecturer always welcomes the questions asked by the students. Most importantly, the lecturer was very discipline." Other positive comment stated that: "The lecturer absolutely understood how to deliver the materials to the students".

There were more positive comments regarding the ability of the lecturers in managing the courses for the lecturers who used SBD. It happened because the requirements that should be developed and implemented by the SBD grant participants include a systematic description of learning outcomes, clarity of concepts taught along with the online assignments, and course sequencing. The online activity was also supported by Exelsa Moodle and hot potatoes that can be used to upload the material, assignments, quizzes, and a series of lectures systematically. Thus, it is understood that the management of the courses which utilized SBD was perceived better by students than those that did not utilize SBD.

\section{Comparative Analysis of Lecturers' Ability in Empowering Students}

From the data analysis, it was known that there was a significant difference in the ability of the lecturers who used SBD with those who did not useSBD in empowering students. The lecturers who used SBD had better score than those who did not use SBD in empowering students. Referring to PAP type I, the score of the lecturers who used SBD in empowering the students was in the high 
category, while the lecturers who did not use SBD was included in moderate category. The aspects examined in regard with the ability of the lecturers in empowering the students cover three things: 1) the ability of the lecturers to encourage the students' critical/creative thinking, 2) the ability of the lecturers to improve the students' conceptual understanding, and 3) the ability of the lecturer in showing the relevance between topics/themes.

In general, the students provided positive comments on the ability of lecturers who used SBD. It appeared from some examples of the comments as follows: "This course is a subject that interests me, especially the practicum experience that is new for me". Other positive comment was: "I love the learning activities done in the classroom, it encourages students to actively think and being skillful in listening to the materials being taught." Another comment was: "Improve teaching method that is fun and not boring and stressful".

Nonetheless, there were some negative comments for some lecturers who used SBD, for example: "I am happy with how the lecturer teaches. If possible, while teaching in the classroom, do not just keep quiet and look at the students and busy with the laptop". Other feedback from the students was: "This subject had too many assignments that were considered very burdensome for the students". Another comment was: "The method used by the lecturer I guess was less attractive, and cannot build curiosity, but I keep trying to be curious with the questions given".

On the other hand, for the group of lecturers who did not use SBD, there were some positive comments as well related to the ability to empower students in the learning process, for instance: "This course really helped me to become a creative teacher, because here we are taught to create and innovate, either that in making the materials, a game that includes materials given, poetry, and many more that can be applied in the future". Other positive comment was: "This lecture encouraged me to be able to think critically. I am used to lectures that are not demanding. This subject really requires students to think critically and creatively, and seek learning".

However, there were also some suggestions addressed to some lecturers who did not use SBD, for example: "The teaching method was very monotonous that made us sleepy in class, but we can understand the material". Another suggestion was: "For the future, please don't be monotonous, because during the learning process in class the students got bored".

From the description above, it is understood that the comments for the lecturers who used SBD in empowering the students were more positive because the learning facilities available at Exelsa allow students to upload assignments, make videos and upload them, do online crossword, online quizzes, and online exams. In addition, SBD also encourages students to actively open SIA since the lecturers do not always tell if there are tasks that must be submitted online. SBD facility using Exelsa encourages students to be active both inside and outside the classroom.

\section{Conclusions}

Based on the findings in this study aforementioned in the data analysis 
and discussion, it can be concluded that:

First, there was a significant difference between the effectiveness of learning management by the lecturers who used SBD with those who did not use SBD. Learning management effectiveness by the lecturers who used SBD was perceived higher than those who did not use SBD. The lecturers utilizing SBD were generally perceived by the students as more qualified to manage learning in comparison to those who did not use SBD. The aspects perceived by students in the course management includes two things: 1) clarity of description and course content and 2) clarity of description of the overall learning activity. The learning management by the lecturers who used SBD was perceived more clearly and systematically because the students have been given the overall picture of the learning activities to be undertaken for the whole semester. The learning management by the lecturers who used SBD was perceived more effective due to the design of learning activities that were arranged in a systematic way and tailored to the competencies to be achieved.

Second, there was a significant difference in the ability of the lecturers who used SBD with those who did not use SBD in managing the course according to the students' perceptions. Lecturers utilizing SBD in managing subjects were perceived more capable of managing subjects than those who did not use SBD. The aspects perceived by students include five things: 1 ) the ability of the lecturerin explaining the learning objectives; 2) the breadth and depth of lecturers' knowledge of the subject; 3) the clarity of the concepts taught; 4) the clarity of the materials being taught; and 5) the clarity of course sequencing. Using SBD, the lecturers should include a systematic description of learning outcomes, clarity of concepts taught along with the online assignments, and course sequencing. In addition, the online learning is also supported by Exelsa Moodle and hot potatoes that can be used to upload the material, assignments, quizzes, and a series of course activities systematically.

Third, there was a significant difference in the ability of lecturers who used SBD with those who did not use SBD in empowering students. The lecturerswho used SBD got better score than those who did not use SBD in empowering students. The score of lecturers who used SBD was put in the high category, while the lecturers who did not use SBD were included in the moderate category. The aspects examined in regard to the ability of the lecturers in empowering the students include three things: 1) the ability of the lecturers to encourage critical/creative thinking of the students, 2) the ability of the lecturers in improving students' conceptual understanding, and 3) the ability of the lecturers to show the relevance between topics/themes. The learning facilities available at Exelsa allow students to upload assignments, make videos and upload them, and do online crossword, online quizzes, and online exams. The learning facilities in Exelsa encourage students to be active both inside and outside the classroom.

\section{Suggestions}

There are some suggestions that can be proposed from this study for the lecturers, study programs, university and the students. First, the lecturers are expected to be more willing in utilizing SBD in managing learning. The 
utilization enables lecturers and students to be well prepared with the overall picture of the learning process from the beginning to the end of the semester.SBD facilitates the lecturers to prepare all course material for the whole semester and then upload them in Exelsa. On the other hand, the students are conditioned to always upload assignments, quizzes, and tests online. Thus, learning can take place more effectively.

Second, the lecturers are expected to be more willing to take advantage of SBD in managing the courses. It is necessary because there are many benefits to be gained by managing SBD courses. The utilization of SBD enables the lecturers to manage the course online, the students to be more engaged, interactions between lecturers and students to be more intensive both inside and outside the classroom, as well as content and evaluation of learning to be understood by the students from working quizzes, assignments and exams that can be done off campus. The lecturers are also encouraged to be more open and to develop the willingness to learn to use SBD as an online learning tool given that the lecturers educate students who live in the digital age.

Third, the heads of the study programs as well as the lecturers are expected to improve the ability in utilizing SBD through participation in many trainings on SBD utilization, video making, and interactive ppt. If all heads of study program encourage their lecturers to take advantage of the SBD, undoubtedly USD will be a campus that optimally utilizes SBD and implements online learning. Thus, the use of SBD becomes a collective movement to optimize the guidance and services for the students.

\section{References}

Acilar, A. (2011). Exploring the aspects of digital divide in a developing country. Bilecik University, Turkey.

Chen, W., \& Wellman, B. (2004). The global digital divide - Within and between countries. IT \& Society, 1(7), 39-45.

Ferro, E., et al. 2010. Handbook of Research on Overcoming Digital Divides: Constructing on Equitable and Competitive Information Society. Volume 1. Information Science Reference. New York: Hershey.

Hidayatullah, S. 2013. Pengukuran Kesenjangan Digital di Dinas Perkebunan dan Peternakan Kabupaten Tapanuli Selatan. Tesis. Padang: Program Magister Chief Information Officer, Fakutas Teknik, Universitas Negeri Padang.

Juraman, S. R. 2014. Pemanfaatan Smarthphone Android Oleh Mahasiswa Ilmu Komunikasi Dalam Mengakses Informasi Edukatif. Journal Unstrat Volume III, No.1 Tahun 2014.

Majid, A. 2007. Perencanaan Pembelajaran. Cetakan III. Bandung: Rosda Karya. P3MP-LPM USD. 2012. Buku Panduan Untuk Dosen: Exelsa Berbasis Moodle. Yogyakarta: P3MP-LPM USD.

P3MP-LPM USD. 2015. Panduan Praktis Tool Hot Potatoes. Yogyakarta: P3MPLPM USD.

Rallis, H. M. 2009. Digital Natives and Digital Immigrants: Exploring the Intergenerational Digital Divide. xxx : UMD. 
IJIET, Vol. 1, No. 1, January 2017

Rohani, A. 2004. Pengelolaan Pembelajaran. Cetakan ke-2. Jakarta: PT. Rineka Cipta.

Sadiman, A. S., dkk. 2008. Media Pendidikan: Pengertian, Pengembangan dan Pemanfaatannya. Jakarta: PT. Raja Grafindo Persada.

Tiene, D. 2002. Addressing the Global Digital Divide and It's Impact on Educational Opportunity. Kent, USA: Routledge.

Tim P3MP-LPM USD. 2012. Buku Panduan Untuk Dosen: Exelsa Berbasis Moodle. Yogyakarta: P3MP-LPM USD.

Undang - Undang Republik Indonesia Nomor 14 Tahun 2008 tentang KIP (Keterbukaan Informasi Publik)

Zulham, M. 2014. Kesenjangan Digital di Kalangan Guru SMP (Studi Deskriptif Mengenai Kesenjangan Aksesibilitas dan Kapabilitas TeknologiInformasi di Kalangan Guru SMP Kecamatan Krian. Surabaya: FISIP Universitas Airlangga.

Web: http://www.bced.gov.bc.ca/irp/appskill/ asleares.htm January 28, 1999. 